\title{
Unique development of narratological approaches to the apocryphal or deuterocanonical books of the Septuagint with special emphasis on the North-West University scholarship
}

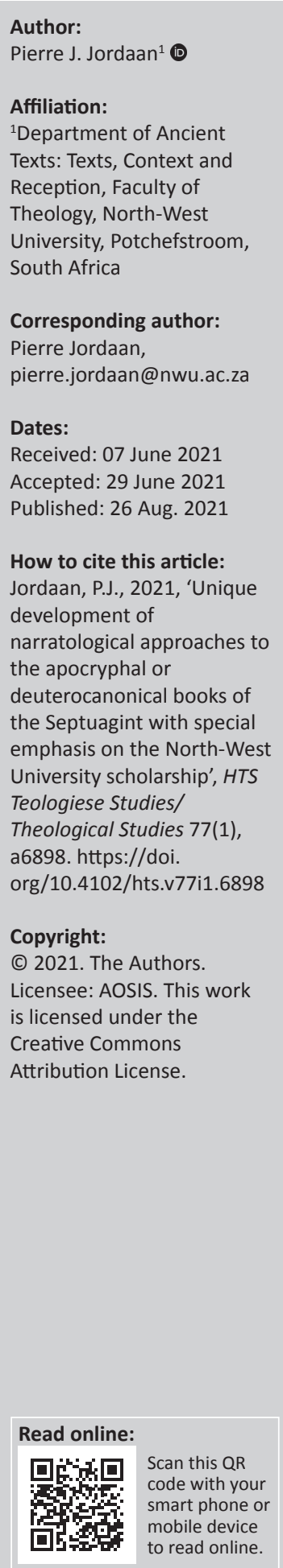

This article aims to present a brief historical overview of interpretative theories and methods relevant to those books that are included in either the Protestant Apocrypha or the Catholic Deuterocanonical in the LXX (Septuagint) for the period 1891-2020. The aim of the article is not to give a complete description of all research on apocryphal/deuterocanonical books. The author's journey with the relevant literature commenced in 2006, when he was appointed as one of the translators of apocryphal texts for a new edition of the new Afrikaans Bible (2020). Initially, he felt trapped as if in a maze. However, as his research progressed and as he met and talked to LXX experts at that stage, the road began to seem less of an obstacle and more like a challenge. One of the important aspects that he discovered was that not every text in the LXX has a so-called Hebrew Vorlage. Although the author describes different approaches used to interpret LXX material, for example historical-grammatical methods, his focus is on South African LXX research that has made a unique contribution to the previous and existing research, especially by the researchers of the North-West University.

Contribution: The article briefly discusses several researchers who have made unique contributions to the LXX apocryphal/deuterocanonical research during the last decade. These scholars utilised different methods to interpret the LXX texts - methods that were not previously employed regularly if at all, for example narratology and narrative theory, cognitive linguistics, cultural anthropology, semiotic theory, rhetorical theory and performance theory.

Keywords: Protestant Apocrypha; Deuterocanonical; Septuagint; research methodology; North-West University; narratology; cognitive linguistics; semiotics; historical-grammatical; Greimassian.

\section{Introduction}

In the year 2006, I was asked to act as a translator for the new Afrikaans Bible. I was selected to translate certain books of the Protestant Apocrypha. These books overlap somewhat with what the Roman Catholics would term, the Deuterocanonical books. The specific book I had to translate was 2 Maccabees, which serves as pars pro toto for the purpose of this paper.

I was, to say the least, fascinated by these texts that I saw for the first time in my life. Not only did the Greek text intrigue me, but also the narratives. Consequently, I needed to know more about these texts, and I tried to find a larger audience interested in them.

My search brought me into contact with Johann Cook of the University of Stellenbosch and Gert Steyn of the University of Pretoria. Steyn and Cook constantly reminded me to keep in mind that the texts of the LXX are related to a Hebrew Vorlage that had to be reckoned with. The concept of a Hebrew Vorlage pre-supposes a Hebrew text thought to be older and more original than the Greek text of the LXX. The idea was to put the Hebrew and the Greek texts next to each other to establish a more authentic reading of the Hebrew text at hand. In essence, this was a text-critical/ redaction-critical approach centring around the Hebrew text. In my mind this approach was not satisfying; I suspected that there was more to be said about the Greek text.

I was pleasantly surprised to learn that there were texts, for example 2 Maccabees, the Additions to Daniel and Judith that do not have a Hebrew Vorlage. These texts could be considered as

Note: Special Collection: Historical Thought and Source Interpretation, sub-edited by Johann Cook (Stellenbosch University). 
standing on their own with specific textual traditions. They would also have their own Lebensraum, Gattung and Sitz im Leben. Naturally, narrative theory would be part and parcel of such research, as most of them were typically Jewish narratives.

This sent me on a search for interpretative models of these texts. I discovered that the initial method of interpretation was historical-grammatical, putting the grammatical structures and the textual traditions under scrutiny. Commentaries on these texts often included dogmatic observations, depending on the ecclesiastical tradition of the commentator. Two commentaries, both published more than a century ago, can be situated within this paradigm. The first commentary was authored by Böckler (1891), who presented extensive explanations why the Apocrypha was not taken up in the canon. The second commentator from this era was Moffatt (1913), who focussed on the strangeness of the theology of these books. In this initial stage, not much progress had been made on the narrative aspects of the apocryphal/ deuterocanonical literature. In a way, the First World War might also have inhibited the progress of scholarship.

Bickerman (1937) made a significant contribution with his book Der Gott der Makkabäer: Untersuchungen über Sinn und Ursprung der makkabäischen Erhebung (English translation, 1979), in which he argued that strife portrayed in 1 and 2 Maccabees was not between the Jews and the Seleucids, but rather amongst the Jews themselves. He distinguished a proHellenistic and an orthodox Jewish party. For the first time, the importance of the socio-historical background of the narratives was stressed. Bickerman (1979:xii), in his Foreword to the English translation of this book, openly admitted that he was influenced by the infighting among the Jews in Berlin before the Second World War to come to this viewpoint.

Tcherikover (1982) expanded on the idea of 'revolution' (Erhebung) that Bickerman discussed in his commentary. He saw the uprising in Jerusalem (c. 167-160 BCE) as coming from the populace and spreading to the countryside against the aristocracy and the Temple elite (1959:192-193). The temple in Jerusalem was ruled by a pro-Hellenistic high priest. The temple was the hub of economic activity, which the faithful visited regularly to perform sacrificial offerings. The pro-Hellenistic temple elite disenfranchised the general population and deprived them of doing business. This resulted in dissatisfaction, which quickly spread from Jerusalem to the surrounding areas. The pro-Hellenistic movement saw the Hasidim as a threat to the welfare of the state, and in effect undermining the state's political and social equilibrium. This hostility between the opposing parties escalated to the point that a civil war was inevitable. The value of Tcherikover's contribution to the narrative lies in the fact that he describes the narratives of the opposing parties and their theological tendencies more accurately than Bickerman. The Seleucid colonists with their templepolluting polytheistic religion wanted to turn Jerusalem into a Greek polis. According to Tcherikover (1982:195), the Jewish masses did not appreciate what was happening to their temple. When Bickerman and Tcherikover looked at the political situation behind the revolution, Nickelsburg openly admits the value of narrative critique in general.

Nickelsburg (2005) strongly argued in favour of the importance of the narratives in apocryphal literature in general when he says:

I am interested not simply or primarily in ideas or motifs or in contents in some amorphous sense, but in literature that has form and direction: in narrative that has plot with beginning, middle, and end (or situation, complication, and resolution); in other types of literature that use particular forms and rhetorical devices with consistency and purpose. The critic's task is to find these forms and directions and to interpret the text with reference to them. (p. 3)

Jan Willem van Henten (1997) applied this observation by Nickelsburg in his book on 2 and 4 Maccabees in which he acknowledged the importance of narrative critique. He identified six successive elements when looking at the martyr narratives of 2 and 4 Maccabees. It would also seem that by this time (i.e. 1990s) narrative critique had become a standard point of departure when looking at deuterocanonical/ apocryphal literature.

After narrative critique became a recognised theory for interpreting 2 Maccabees, no other major commentator would write an article or commentary on 2 Maccabees without explicitly emphasising their narrative approach to apocryphal literature. In this regard, it is important to mention Daniel Schwartz with his De Gruyter commentary in which he clearly recognised the value of narrative critique (cf. 2008:55-66).

Robert Doran (2012) was a relatively recent scholar who took the narrative structures and the important role they play in constructing a text seriously, as is clear in the following words on the first page of his commentary (2012):

It is a highly rhetorical narrative that sets out not to give a blow by blow description of events but to move the audience to commit to faithfully following the ancestral traditions of Judaism. (p. 1, [author's own emphasis])

Doran hereby recognised and discussed two important aspects of 2 Maccabees, namely that the rhetoric devices and the narratives in the text had the intention to promote Judaism in the minds of the readers (cf. 2012:3-4, 10, 35, 37, $53,69-71,164,181-182,191-192,275,296,298)$. At this stage, it seems that the importance of narrative critique on the Apocrypha in South Africa had, because of various factors, gone full circle by 2012:

- It started in a maze in 2006 with myself, not knowing in which direction to go. I began by exploring the historicalgrammatical method. I did not have a ball of thread in my hand to help me get out of the maze as Theseus received from Ariadne. I started this journey into an academic world that sometimes felt like an inescapable labyrinth.

- As my research continued, the realisation came that certain of the texts we are interested in have no Hebrew Vorlage. This meant that our focus would not be to 
investigate the authenticity of Hebrew texts, but rather the Greek texts in the LXX.

- The importance of narrative critique by various scholars, starting with Bickerman in 1937 through to Doran in 2012, was discovered and began to establish itself as an authentic theoretical approach in the Apocrypha research. This meant that we have now read ourselves out of the maze and felt better prepared to inaugurate serious narrative research on the Apocrypha.

\section{Taking the Apocrypha in the LXX seriously as narratives}

With the aforementioned in mind, it means that, in South Africa, we started a novel strand of research of the Apocryphal LXX books, namely narratological research. Narratology entails the study of narrative and narrative structures in texts and how they affect human perception. Investigating texts as narratives has been with us for at least two millennia, commencing with the Greek philosopher Aristotle's Poetics (cf. Amerian \& Jofi 2015; Jahn 2020; Landa \& Onega 2014).

From the beginning, this new direction in our more local research of the LXX texts encompassed individual publications by scholars as well as papers presented at LXX-based conferences, which were frequently published in book form. The following paragraphs present a short historical overview of this process.

\section{Publications by researchers of the North-West University ${ }^{1}$} The influence of Greimas

We were privileged to welcome a student from the DRC (Democratic Republic of Congo) at the Potchefstroom Campus of the NWU (North-West University), namely Dichk Kanonge, who is extremely knowledgeable about the narrative theory as developed by Algirdas Julien Greimas. ${ }^{2}$

Kanonge is also a Francophone and therefore has access to the French texts by Greimas. He introduced Greimas extensively to the interpretation of LXX literature in South Africa. Colleagues from other language departments at the NWU such as the Afrikaans and English departments envied the Greek department for having the likes of Kanonge as a researcher who is well versed in Greimas' theory and method. Kanonge completed his doctorate on Susanna in the Additions to Daniel (2009) which was accepted with high acclaim and lauded by external examiners. He mastered the highly complex discussion of Greimassian semiotic analysis in a way never done before in the Apocrypha research. Kanonge investigated the text as a narratological artefact on the following three levels:

\footnotetext{
1 Because of the limits set in terms of the number of sources allowed in the reference list, only a small number of articles by each researcher were included - articles for which they were the sole author.
}

2.Cf. Kanonge (2009:216) and the bibliography for a list of publications by De Greimas.
- Firstly, the figurative analysis of a narrative. It entails investigating the figurative oppositions, motifs and employment of narratives. Figures, that is 'characters', are created in opposition to each other to transmit certain values to the reader/hearer. Such figures desire to discourage certain anti-values according to the author's point of view or ideology.

- Secondly, the structural analysis of the narrative. This entails the so-called actantial configuration, which describes the relation between actant and anti-actant in the narrative. This part of a narrative focusses on the addressor (e.g. God) and the addressee (e.g. the faithful observers of the Law). The object of the quest (e.g. the Jewish faith) is also described.

- Thirdly, the canonical narrative schema is developed. This focusses on the itinerary of the protagonist (heroine/ hero) in the entire narrative. This entails how the protagonist is contracted, acquires competence, performs cordially and is sanctioned or deemed worthy/unworthy.

- Lastly, a thematic analysis is conducted, which is an investigation into the fundamental values that generated the narrative. Contrasting values in the narrative are studied by using the semiotic square as developed by De Greimas.

Kanonge's D.Litt. research led to the publication of articles published in various journals. In these articles, Kanonge discusses the different aspects of his research in more depth (2014, 2018).

Hobyane (2012) followed suit by utilising Greimas' theory. In his case, the text under investigation was the apocryphal book of Judith. Using a Greimassian approach, Hobyane investigated the figurative, the narrative and thematic levels of analysis. He concluded that Judith was written to encourage tenacity against anti-Judaistic tendencies and rejuvenating Jewish religion in the Second Temple period. He further made the inference that it is possible to develop a theory of Judith's purpose by employing a Greimassian narratological approach, irrespective of the date of origin assigned to the text. Thus far, Hobyane has published 11 articles since finishing his D.Litt. degree of which only four are referred to here (2015a, 2015b, 2016a, 2016b).

The Greimassian semiotic approach to interpret narratives as employed by Kanonge and Hobyane gave birth to at least 20 articles in peer-reviewed journals. This represents an important development within the environment of narratological research of the LXX literature in South Africa, which was soon followed by another method, namely rhetorical analysis.

\section{Rhetorical structure and LXX texts}

One of Jordaan's master's degree candidates who investigated an apocryphal text was Hefer (2012). Hefer's dissertation perused a variety of issues related to the martyr deaths in 2 Maccabees. This was undertaken specifically from the theoretical perspective of cultural anthropology as developed by Bruce Malina and Pilch (1998), Malina (2001) and Neyrey 
(1996, 1998, 2005). These issues concerned wholeness, honour and shame, sacred and profane, pure and impure, patronclient relationship and individual-group relationship. Hefer's finding was that it is not obvious from the narrative whether the Jewish community would have made a clear-cut decision in favour of martyrdom as a result of the culturalanthropological and religious idea that torture and mutilations in itself were regarded as disgraceful. However, he indicates that the community could have been moved towards a positive outcome through the use of an emotional argument.

In 2009 a postdoctoral fellow was appointed to work alongside Jordaan, namely Philip Nolte (2009-2012). Nolte experimented with theoretical and methodological frameworks underutilised and/or not employed for apocryphal research at that time. He began his fellowship by researching the possibilities of cognitive linguistics as theory and method, which turned out to present interesting avenues of interpretation of apocryphal literature. Nolte brought different theories and methods into play in his investigations of the LXX texts, which led to several published articles (Nolte \& Jordaan 2009, 2012, 2013, 2016, 2021). These publications reveal an interest in different vantage points from which texts can be read, namely (1) cognitive linguistics; (2) narrative theory, with a specific focus on Michel Foucault's insights in this area; (3) the social construction of reality as described by Peter Berger and Thomas Luckmann; (4) reader-response criticism; (5) studies on intertextuality; (6) referential systems of repertoire and systems theory; and (7) Greimassian semiotics.

Reading apocryphal literature from the viewpoint of rhetorical analysis was initiated by Eugene Coetzer (2015) in his PhD dissertation. He applied rhetorical analysis to focus on the dynamics within the narratives. Initially, he discovered various counter-narratives in his analysis of 2 Maccabees. Later on, he became more careful in his arguments in favour of counter-narratives by rather seeing the narratives as part of a process. He starts his analyses from what he calls the 'ground zero' of ideological innovative communication in the narrative. He asks questions, such as how literary devices negotiate the shift from orthopraxical ideas towards heteropraxy. He does this by showing how heteropraxy became orthopraxy again and thus creates a new counter-narrative. Although he strongly propagates the idea of counter-narratives, he also pleads for a gradual implementation of new ideas. Coetzer's thesis set him off to publish several articles (2016a, 2016b, 2016c, 2020, 2021). Over against Coetzer, Jordaan works explicitly with counter-narratives when interpreting apocryphal texts. In a Brill publication on Judith (2009:334-335), Jordaan proposed a definite counter-narrative that would encourage women, foreigners and slaves to participate in the Jewish cause.

Another excellent scholar worth mentioning here is Jacobus De Bruyn (2015a), ${ }^{3}$ a master's degree graduate of Jordaan, who employed narrative critique to examine the functioning

3.De Bruyn completed a PhD on Old Testament Science at the University of Pretoria in 2009. of body and space in the apocryphal story of Bel and the Dragon. De Bruyn's theoretical paradigm and method built on insights from cognitive linguistics as developed by Lakoff and Johnson (1999) and Lakoff (2008). This investigation by De Bruyn promoted multidisciplinary research of LXX texts by utilising a variety of research methods not deemed possible before. De Bruyn and Jordaan were not afraid to move boundaries, especially relating to the reception of the Apocrypha within Protestant Christian faith communities (eds. Jordaan \& Allen 2016:4). De Bruyn has published 15 articles on his own of which only 5 are included here (2015b, 2015c, 2015d, 2015e, 2016).

An exceptional scholar who takes a road less travelled in studying ancient Jewish texts is Nicholas P.L. Allen. He was briefly one of Jordaan's doctoral students (PhD [Greek] 2015), and since 2013 he has focussed mostly on Cognate Literature (Josephus) and various Deuterocanonical books. Allen calls his approach 'interpretivist/constructivist' and sets it apart from what he calls a 'naive positivistic' approach. Allen's theoretical and methodological approach is as follows: (1) he explicitly acknowledges that all worldviews are socially constructed and that all researchers have to keep that in mind; (2) he employs mixed methods (quantitative and qualitative methods) in his inquiry into the texts; (3) he argues that knowledge is mediated solely by language which is influenced by our subjective worldviews (2021:21-22). Allen has been a prolific researcher and author as can be seen in at least 11 articles and chapters in books, of which only a few have been referred to here $(2016,2018,2019,2020,2021) .{ }^{4}$

Significantly, Jordaan's students, research fellows and colleagues at the NWU published nearly 100 articles and chapters in journals and books from 2009 onwards. This is in no small part because of Jordaan's enthusiasm and motivation of the researchers working with him. Apart from acting as study leader for several successful master's and doctoral candidates, as well as being a colleague of and mentor for postdoctoral fellows, Jordaan published and co-published at least 30 articles from 2008 onwards. These publications are only the ones related to research on LXX material (e.g. 2015, 2016a, 2016b, 2017, 2020, 2021). He was also deeply involved in organising several LXXSA conferences and delivered numerous papers locally and abroad, for example Hungary, the Netherlands and the USA. Jordaan's colleagues and students became familiar faces and names during LXX conferences. He acted as co-editor for at least three international publications $(2016,2021)$.

An important development is that some students who have obtained their doctoral degrees under Jordaan's guidance have been appointed as professors and postdoctoral fellows at universities: Kanonge was appointed as professor in the DRC; Hobyane and Allen as professors at NWU; Coetzer as a postdoctoral fellow at the University of KwaZulu-Natal. It is noteworthy to mention that Hobyane and Jordaan have both obtained National Research Foundation (NRF) ratings.

4.Allen completed a DPhil in Art History at U.D.W. (now UKZZN) in 1995. 


\section{Conferences and publications of conference proceedings}

In July 2013 the LXXSA (Association for the Study of the Septuagint in South Africa) convened a conference at the NWU campus of Potchefstroom, North West Province, which attracted world-renowned scholars such as Atalya Brenner, George Nickelsburg and Jan Willem van Henten. The papers delivered at the conference were published in 2016 in Biblische Notizen by the publisher Verlag Herder Freiburg im Breisgau as Body, Psyche and Space in Old Testament Apocryphal Literature. During this conference, specific focus was placed on the body, psyche and space in the Old Testament apocryphal literature. The following themes were presented, examined and discussed at the conference: Greimassian semiotics, the embodiment of holiness, the politics surrounding female bodies, narrative critique, body and space. All these approaches differ from the so-called traditional approaches in the sense that they venture onto new roads concerning LXX research.

The 14 essays delivered at the LXXSA conference in August 2015 at the NWU, Potchefstroom, resulted in a De Gruyter publication titled Construction, Coherence and Connotations: Studies on the Septuagint, Apocryphal and Cognate Literature (2016). Although the LXXSA is a young organisation (founded in 2007), it has achieved much in its short history. The goal of the 2015 conference was to apply critical theory and approaches to Old Testament and Apocryphal and Cognate literature that have hitherto not been explored. The intention was to bring recent research on the Old Testament Apocrypha and the so-called pseudepigraphical literature to the fore and critically review where research stood at the time. An interesting part of the introduction in this publication was the inclusion of a SWOT (strengths, weaknesses, opportunities, threats) analysis of the LXXSA (Jordaan \& Allen 2016:3-5). One of the strengths indicated was the quality and character of the specific group of academics who are described as 'largely tolerant and accommodating of each other in terms of methodologies and approaches' and 'passionate about their subject matter' (Jordaan \& Allen 2016:6). Two of the weaknesses acknowledged are that very few women and ethnic African scholars are part of this largely white, male-dominated group of academics (Jordaan \& Allen 2016:6).

Yet another conference on South African soil was the congress on the Septuagint at Stellenbosch University in 2018 under the auspices of the Department of Ancient Studies. The 19 papers presented at the congress are categorised under three rubrics, namely (1) Introduction and questions of methodology; (2) Septuagint and Plato: Methodological considerations and models of interpretations; and (3) Theological aspects of the Greek Bible: Translations and Greek literature. The proceedings of this congress were published by SBL Press under the title: Toward a Theology of the Septuagint (2020). In a significant chapter by Jordaan (2020:295-316), he endeavoured to demarcate the main features of research on 2 Maccabees over the past century. He revealed that the research can be divided into four quests, representing four chronological periods. The fourth quest represents the current era, from 2012 until the present day. ${ }^{5}$

In this context, Honigman (2014) can be viewed as a pioneer. Honigman sought to shed new light on the so-called Antiochus IV persecution in Jerusalem (c. 168 bce). She did this by recontextualising Antiochus IV's actions concerning assumed, predominant, Judaean literary conventions. What makes her approach unique is that she favours a literary analysis to both 1 and 2 Maccabees, questioning the viability of a more positivistic approach. Both books clearly state that the persecution by Antiochus IV was religious in nature something that Honigman has seriously challenged. Assuming that both authors adhered to identical cultural codes, Honigman treats the discourse in both 1 and 2 Maccabees as framing narratives, or 'literary codes'. She challenges other scholars as having incorrectly dealt with these texts at face value, naively assuming that they accurately refer to the religious persecution of the Jews. Honigman believes that the authors of 1 and 2 Maccabees portrayed a strictly symbolic universe and never intended to reproduce information that applied to the real world per se.

Another result of the new research of narratives in the LXX was the formation of the Hungaro-South African study group.

\section{The Hungaro-South African Study Group}

The Hungaro-South African Study Group (HSASG) was founded in 2016 as an outcome of cooperation between SACRIA - Septuagint and the Cognate Literature Research Initiative for Africa (Allen \& Jordaan in South Africa) as well as prominent Hungarian scholars: József Zsengellér, Ibolya Balla and the late Géza Xeravits (2014). In many ways this was to become a vehicle for the 'fourth quest' research. An international conference was first held in Budapest, cohosted by the NWU (South Africa) and Károli Gáspár Reformed University (Hungary) in September 2017, with the theme set as 'Passion, Persecution, and Epiphany in Early Jewish Literature'. The invited keynote speakers were: Johann Cook, Steve Mason, Friedrich Reiterer and Jan Willem Van Henten.

One of the significant outcomes from this initiative was the publication of an academic book by Routledge (2020) under the title: Passion, Persecution, and Epiphany in Early Jewish Literature. The chapters cover a wide variety of texts such as Daniel, Lamentations, LXX version of Proverbs, LXX portrayal of the David-Bathsheba-Uriah affair, 2 Maccabees 7 and 9, Josephus Flavius and Wisdom 2:19. Reading strategies utilised to elucidate these texts include an interpretive/ constructivist approach, text-conceptual dissonance (adapted from cognitive dissonance), discourse strategy, dramatic

5.According to Jordaan the 'fourth quest is identifiable by the advent of newer methods of interpretation to 2 Maccabees. ... Research on 2 Maccabees has surely methods of interpretation to 2 Maccabees. ... Research on 2 Maccabees has surely
entered an exciting phase' (2020:313). Jordaan further stated, 'the time of a new entered an exciting phase' (2020:313). Jordaan furth
commentary on 2 Maccabees has come' (2020:314). 
irony, classical tragedy, rhetorical theory and culturalanthropological theory (warfare imagery, shame and honour and challenge and response).

Another international conference of the HSASG was held in December 2018 on the Potchefstroom campus of the NWU with the theme: 'Deities at War: Rhetoric in 2 Maccabees'. The keynote speakers for this conference were Friedrich Reiterer and József Zsengellér. Three years later, based on this event and the contributions of other researchers, an academic book was launched with the title: Rhetoric in 2 Maccabees: Challenging God (2021) by Cambridge Scholars Publishing. The target group for this volume was scholars interested in the Deuterocanonical books with special emphasis on 2 Maccabees.

Most recently, Allen and Balla organised an international conference in Pápa, Hungary (18-20 September 2019). This event was hosted by the Pápa Reformed Theological Seminary. The theme was 'Trauma, Turmoil and Tenacity in Early Jewish Literature'. The keynote speakers were Steyn and Reiterer. Based on the outcomes of this event plus the latest contributions of leading Austrian, German, Hungarian, Romanian, South African and US scholars, an edited academic book (Allen \& Doedens) is coming out this year (2021). This is tilted: Turmoil, Trauma, and Tenacity in Early Jewish Literature.

\section{Conclusion}

This article has attempted to present a short historical survey of major eras in $\mathrm{LXX}$ research with special reference to the role played by recent NWU scholarship. A quick reading will reveal that the article contains a prevalence of research on 2 Maccabees. However, when the publications of LXX conferences are investigated, it becomes clear that a plethora of apocryphal/deuterocanonical books have been investigated over the years. This article has briefly mapped a specific aspect of apocryphal/deuterocanonical-based research, namely how different theoretical and methodological approaches seemed to be characteristic of certain eras, starting in 1891. The author has already described these phases as a series of four 'quests' in previous research (cf. Jordaan 2020). This article has shown that South African research contributed in unique ways to the fourth quest in apocryphal/deuterocanonical research. This unique development became clear in the different theories and methods used by certain South African researchers as from approximately 2008 and 2009. These researchers were mostly based at the NWU on the Potchefstroom campus.

\section{Acknowledgements Competing interests}

The author declares that he has no financial or personal relationships that may have inappropriately influenced him in writing this article.

\section{Author's contributions}

P.J.J. is the sole author of this article.

\section{Ethical considerations}

This article followed all ethical standards for research without direct contact with human or animal subjects.

\section{Funding information}

This research received no specific grant from any funding agency in the public, commercial or not-for-profit sectors.

\section{Data availability}

Data sharing is not applicable to this article as no new data were created or analysed in this study.

\section{Disclaimer}

The views and opinions expressed in this article are those of the author and do not necessarily reflect the official policy or position of any affiliated agency of the author.

\section{References}

Allen, N.P.L., 2016, 'Judith: Embodying holiness in a G-dless Space', Biblische Notizen $168,17-44$.

Allen, N.P.L., 2018, 'Counting half-shekels-Redeeming souls? in 2 Maccabees 12:38-45', HTS Teologiese Studies/Theological Studies 74(3), 1-10. https://doi. org/10.4102/hts.v74i3.5011

Allen, N.P.L., 2019, ' 3 Maccabees as a monomyth', HTS Teologiese Studies/Theological Studies 75(3), 1-6. https://doi.org/10.4102/hts.v75i3.5497

Allen, N.P.L., 2021, 'The Epitome of 2Maccabees: The rhetoric of a new theology of salvation', in N.P.L. Allen \& P.J. Jordaan (eds.), Rhetoric in 2Maccabees: challenging God, pp. 16-41, Cambridge Scholars Publishing, Newcastle Upon Tyne.

Allen, N.P.L., Jordaan, P.J. \& Zsengellér, J. (eds.), 2020, Passion, persecution, and epiphany in early Jewish literature, Routledge, New York, NY.

Amerian, M. \& Jofi, L., 2015, 'Key concepts and basic notes on narratology and narrative', Scientific Journal of Review 4(10), 182-192. https://doi.org/10.14196/ sjr.v4i10.1927

Bickerman, E.J., 1937, Der Gott der Makkabäer: Untersuchungen über Sinn und Urpsrung der makkabäischen Erhebung, Schocken Verlag, Berlin.

Bickerman, E., 1979, The God of the Maccabees: Studies on the meaning and origin of the Maccabean revolt, Brill, Leiden.

Böckler, O., 1891, Die Apokryphen des Alten Testaments nebst einem anhang über die Pseudepigraphenliteratur, Beck, Munich.

Coetzer, E., 2015, 'A rhetorical analysis of 2 Maccabees', Unpublished doctoral thesis, North-West University.

Coetzer, E., 2016a, 'A spatial analysis of the reference to heaven in 2 Maccabees', Biblische Notizen 168, 105-115.

Coetzer, E., 2016b, 'Heroes and villains in 2 Maccabees 8:1-36 - A rhetorical analysis' Old Testament Essays 29(3), 419-433. https://doi.org/10.17159/2312-3621/ 2016/v29n3a4

Coetzer, E., 2016c, 'Coincidence or coherence? Rhetorical considerations for unnatural elements in 2 Maccabees 5:1-20', in P.J. Jordaan \& N.P.L. Allen (eds.), Construction, coherence and connotations: Studies on the Septuagint, Apocryphal and Cognate literature, pp. 249-260, De Gruyter, Berlin.

Coetzer, E., 2020, 'Victorious victims and prayers for the deceased: Possible links between conceptual tension and progressive doctrine in 2 Maccabees 12', in N.P.L. Allen, P.J. Jordaan \& J. Zsengellér (eds.), Passion, persecution, and epiphany in early Jewish literature, pp. 31-46, Routledge Taylor and Francis, London.

Coetzer, E., 2021, 'An old fire and a new idea: The network of conceptual linkages in the second prefixed letter of 2 Maccabees', in N.P.L. Allen \& P.J. Jordaan (eds.) Rhetoric in 2 Maccabees: Challenging God, pp. 65-78, Cambridge Scholars Publishing, Newcastle Upon Tyne.

De Bruyn, J.J., 2015a, 'Constructing realities: Body and space in Bel and the dragon' Unpublished master's dissertation, North-West University.

De Bruyn, J.J., 2015b, 'Dining in the lions' den - Bel and the dragon, verses 28-42 (Old Greek/Theodotion)', Verbum et Ecclesia (Skrif en Kerk) 36(1), 1-9. https://doi. org/10.4102/ve.v36i1.1363

De Bruyn, J.J., 2015c, 'Daniel Dragonslayer - Bel and the dragon, verses 23-27 (OG/ Th)', In die Skriflig 49(1), 1-8. https://doi.org/10.4102/ids.v49i1.1848

De Bruyn, J.J., 2015d, 'Constructing a living deity - Framing the God of Israel in the stories of Daniel and Bel and the dragon', Journal for Semitics/Tydskrif vir Semitistiek 24(1), 65-92. https://doi.org/10.25159/1013-8471/3439 
De Bruyn, J.J., 2015e, 'Susanna - Framing the minds and views of people', Journal for Semitics/Tydskrif vir Semitistiek 24(2), 594-612. https://doi.org/10.25159/1013$8471 / 3470$

De Bruyn, J.J., 2016, 'In Remembrance of God's messianic vessel - "Body" and "space" in Psalm 151', Biblische Notizen 168, 163-183.

Doran, R., 2012, 2 Maccabees: A critical commentary, Fortress Press, Minneapolis, MN

Hefer, B.J., 2012, 'Between honour and shame: Martyrdom in 2 Maccabees 6-7 within the socio-cultural arena', MA dissertation, North-West University, Potchefstroom.

Hobyane, S.H., 2012, 'A Greimassian semiotic analysis of Judith', DLitt dissertation, North-West University, Potchefsstroom

Hobyane, R., 2015a, 'Clashing deities in the book of Judith: A Greimassian perspective', HTS Teologiese Studies/Theological Studies 71(3), 1-8.

Hobyane, R.S., 2015b, 'Actantial model of Judith, a key to unlocking its possible purpose: A Greimassian contribution', Old Testament Essays (New Series) 28(2), 371-394. https://doi.org/10.17159/2312-3621/2015/V28N2A9

Hobyane, R.S., 2016a, 'Body and space in Judith: A Greimassian perspective', Biblische Notizen 168, 3-15.

Hobyane, R.S., 2016b, 'Truth and falsehood in Judith: A Greimassian contribution' HTS Teologiese Studies/Theological Studies 72(3), 1-5. https://doi.org/10.4102/ hts.v72i3.3338

Honigman, S., 2014, Tales of high priests and taxes: The books of the Maccabees and the Judean rebellion against Antiochos IV, University of California Press, Oakland, CA.

Jahn, M., 2020, Narratology 2.1: A guide to the theory of narrative, viewed 24 May 2021, from www.uni-koeln.de/ ame02/jahn narratology2.1.pdf.

Jordaan, P.J., 2009, 'Reading Judith as therapeutic narrative', in J. Cook (ed.), Septuagint and reception, pp. 335-346, Brill, Leiden.

Jordaan, P.J., 2015, 'The Temple in 2 Maccabees - Dynamics and episodes', Journal for Semitics/Tydskrif vir Semitistiek 24(1), 352-365. https://doi.org/10.25159/1013$8471 / 3452$

Jordaan, P.J., 2016a, 'Body, space and narrative in 2Macc 1:1-10a', Biblische Notizen 168, 89-103.

Jordaan, P.J., 2016b, 'Suffering bodies in 2 Maccabees 3', In die Skriflig 50(4), 1-7. https://doi.org/10.4102/ids.v50i4.2173

Jordaan, P.J., 2017, 'A narrative-therapeutic reading of the martyr narrative in 2 Maccabees 6 and 7: The formation of a new type of theology', in N. CalduchBenages, J. Corley, M. Duggan \& R. Egger-Wenzel (eds.), Deuterocanonical and cognate literature: Yearbook 2016/2017, pp. 181-195, De Gruyter, Berlin.

Jordaan, P.J., 2020, 'Toward defining the fourth quest in 2 Maccabees research', in J. Cook \& M. Rösel (eds.), Toward a theology of the Septuagint, pp. 295-316, SBL Press, Atlanta, GA

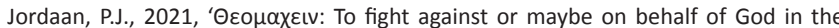
martyr narrative of 2 Maccabees 7:19: Who is fighting whom?', in N.P.L. Allen \&
P.J. Jordaan (eds.), Rhetoric in 2Maccabees: Challenging God, pp. 79-90, Cambridge Scholars Publishing, Newcastle Upon Tyne.

Jordaan, P.J. \& Allen, N.P.L. (eds.), 2016, Construction, coherence and connotations: Studies on the Septuagint, Apocryphal and Cognate Literature, De Gruyter, Berlin.

Kanonge, D.M., 2009, 'The emergence of women in the LXX Apocrypha: A semiotic study of Susanna', Unpublished doctoral thesis, North-West University.
Kanonge, D.M., 2014, 'Gender and Jewishness: A Greimassian analysis of Susanna', Acta Theologica 34(1), 68-90. https://doi.org/10.4314/actat.v34i1.5

Kanonge, D.M., 2018, 'Être and paraitre: The games of truth in the book of Susanna' HTS Teologiese Studies/Theological Studies 74(3), 1-9. https://doi.org/10.4102/ hts.v74i3.4940

Lakoff, G., 2008, The political mind, Viking, New York, NY.

Lakoff, G. \& Johnson, M., 1999, Philosophy in the flesh: The embodied mind and its challenge to western thought, Basic Books, New York, NY.

Landa, J.A.G. \& Onega, S., 2014, 'Introduction', in J.A.G. Landa \& S. Onega (eds.) Narratology: An introduction, pp. 1-44, Routledge, New York, NY.

Malina, B.J. \& Pilch, J., 1998, Biblical social values and their meaning, Hendrikson, Peabody.

Malina B.J., 2001, The New Testament world: Insights from cultural anthropology, Westminster John Knox Press, Louisville, KY.

Moffatt, J., 1913, 'The Second Book of Maccabees', in R.H. Charles (ed.), The Apocrypha and Pseudepigrapha of the Old Testament, pp. 125-154, vol. 1, Clarendon, Oxford

Nolte, S.P., 2012, 'One text, many stories: The (ir)relevance of reader-response criticism for apocryphal literature in the Septuagint', HTS Teologiese Studies/ Theological Studies 68(1), 1-10. https://doi.org/10.4102/hts.v68i1.1092

Nolte, S.P., 2013, 'The realities people live by. A critical reflection on the value of Wolfgang Iser's concept of repertoire for reading the story of Susanna in the Septuagint', HTS Teologiese Studies/Theological Studies 69(1), 1-7. https://doi. Septuagint', HTS Teologiese
org/10.4102/hts.v69i1.1320

Nolte, S.P., 2016. 'A politics of the female body. Reading Susanna (LXX Additions to Daniel) in a brutalised South African Society', Biblische Notizen 168, 147-161.

Nolte, S.P., 2021, 'The martyr death of Eleazar in 2 Maccabees 6:18-32. A Greimassian approach', in N.P.L. Allen \& P.J. Jordaan (eds.), Rhetoric in 2Maccabees: challenging God, pp. 120-136, Cambridge Scholars Publishing, Newcastle Upon Tyne.

Nolte, S.P. \& Jordaan, P.J., 2009, 'Esther's prayer in additions to Esther: Addition C to LXX Esther. An embodied cognition approach', Acta Patristica et Byzantina 20 293-309.

Neyrey, J.H., 1996, Readers guide to clean/unclean, pure/impure, and holy/profane: The idea and system of purity, viewed 22 May 2021, from http://www.nd.edu/ jneyrey/ purity.html.

Neyrey, J.H., 1998, 'Wholeness', in J.J. Pilch \& B.J. Malina (eds.), Handbook of biblical social values, pp. 204-208, Hendrickson, Peabody, MA.

Neyrey, J.H., 2005, 'God, benefactor and patron: The major cultural model for interpreting the deity in Greco-Roman antiquity', Journal for the Study of the New Testament 27(4), 465-492. https://doi.org/10.1177/0142064X05055749

Nickelsburg, G.W.E., 2005, Jewish literature between the Bible and the Mishnah, Fortress, Minneapolis, MN

Schwartz, D.R., 2008, 2 Maccabees, De Gruyter, Berlin.

Tcherikover, V., 1982, Hellenistic civilization and the Jews, Atheneum, New York, NY.

Van Henten, J.W., 1997, The Maccabean martyrs as saviours of the Jewish people: A study of 2 and 4 Maccabees, Brill, Leiden.

Xeravits, G., 2014, 'The figure of Daniel in late antique synagogue art', in V.K. Nagy \& L.S. Egeresi (eds.), Propheten der Epochen/Prophets during the epochs, pp. 217-232, Ugarit-Verlag, Münster. 